PRE-PUBLICATION DRAFT, PRIOR TO COPYEDITS AND PROOFING. PLEASE

DO NOT CITE WITHOUT PERMISSION OF AUTHOR

Death from Above in Minard's Napoleon Map

Richard Taws

$<$ FL $>$ Ten months before he fled Paris for Bordeaux in september 1870, fearing advancing Prussian troops, French engineer Charles-Joseph Minard made the image for which he is best known, his Carte figurative des pertes successives en hommes de I'Armée française dans la campagne de Russie, 1812-1813.1 Evoked frequently as a milestone in the history of cartography, this image, which shared a page with a lesscelebrated map charting the loss of life in Hannibal's army as it traversed the Alps during the Second Punic War, has since acquired totemic status among statisticians, geographers, and design historians. Edward R. Tufte's memorable if somewhat hyperbolic suggestion that the map "may well be the best statistical graphic ever drawn" has been repeated faithfully by all subsequent scholars. ${ }^{2}$ Yet despite the acclaim it has received-it assumes a venerable place in a genealogy of political infographics that runs from William Playfair to W.E.B. Du Bois, from Florence Nightingale to Forensic Architecture-Minard's stark audit of military fatality is rarely considered in relation to contemporary visual practices other than the statistical cartography that preceded it and 
came after it. ${ }^{3}$ Both the subject of the Carte figurative and the context for its production tend to be muted in discussion of its informational economy, while for art history it has been little more than a curiosity. <<COMP: fig. 1 approx. here>>

This isolation of Minard's practice-and of his most lauded flow map in particular-has become more pronounced in the light of his designs' evident relevance to contemporary techniques for data visualization and his work's status as a precursor to the infographics that now explain our world to us. Certainly, late 2020 seems an appropriate time to reconsider the historical dynamic at play in Minard's calibration of imperial catastrophe. Brightly colored charts of daily rising infections and death tolls-presented with fluctuating degrees of political manipulation-have provided the visual backdrop to our recent encounters with loss. In these, as in Minard's final designs, human deaths are naturalized and aestheticized as landscape features: mountains to climb, curves to flatten. And as if to press home their contemporary charge, Minard's maps are now commonly remade by digital means, repurposed, and tested, with the side effect that their solidity and meaningfulness as objects locatable in a particular historical context is often suppressed. Yet attention to their historical frame reveals an aspect of Minard's Napoleon design that the arresting novelty of his statistical presentation obscures. For his map shared many 
features with existing visual genres-notably military painting and its reproductions-that traded in the representation and calibration of mass death and which had well-developed strategies of their own for presenting documentary evidence with affective immediacy. To think of Minard's work in this way-to suggest that infographics inherited and reworked techniques from contemporary history painting-seems counterintuitive, even regressive, yet serves to redescribe the originality of Minard's Napoleon map, which extrapolated from such works a new statistical accounting of time that was sensitive to multiple media and shifting forms of historical consciousness between the French Revolution and the Third Republic.

Despite Tufte's description of the Carte figurative as "an anti-war poster," the striking appearance of this graphic account of Napoleonic hubris in the waning days of Napoleon III's Second Empire is often downplayed. Although Minard was no revolutionary, the timing of his print's publication was hardly coincidental, and aspects of Minard's own biography provide a helpful resource, for they place his decision-making in the context of broader political and cultural transitions. Yet my ambition is not to offer a fine-grained historical account of Minard's motivations, and certainly not to parse individual works for their conformity to the "facts" they claim to render visible. Rather, this article sets out to consider the kind of history Minard's designs-the chart of 
Napoleon's ruinous Russian campaign in particular-elucidate in the context of their broader visual world.

To suggest that a map might offer an aerial image is hardly an original observation. Yet the omniscient histories from above provided by Minard's flow charts turn out to be a more fraught affair than might be supposed, flipping between a cartographer's transparent aerial scrutiny and more earthly concerns. In his maps movements of people and things are frequently configured as elemental and organic trajectories (of water, of coal, of animal bodies) as well as invisible flows (Minard's 1862 treatise Des tableaux graphiques et des cartes figuratives reproduces a rose map tracking the duration and direction of winds buffeting the Cordouan lighthouse in 1842). ${ }^{4}$ Their perspective unobscured by clouds, birds, or other interference, we see no sign of air as a medium of substance in these designs, although it might appear in concealed form as temperature, shipping volume, direction of travel, or disease. ${ }^{5}$ Rather, the aerial viewpoint of Minard's designs is first and foremost a way of rendering material the statistical data that register the transit of people and things across earth and sea, often transforming in the process the world they traversed. Minard's seemingly neutral overhead views are no such thing. Depicting quantities observed over time as if static phenomena, they offer fluid projections of people or objects stretched through space. Trading in abstractions and adaptations of data as much as certainties, 
they also look sideways to other histories and other forms of representation. Nowhere is this more apparent than in Minard's late Carte figurative, which was not a stand-alone piece but instead participated in a visual ecology that was both contemporary to the time of its production and to the time it represented. The visual vocabularies upon which it drew were not limited to other statistical maps but included dominant genres for representing modern and historical conflict, whether printed images in books and newspapers, photographs, or paintings and their reproductions. ${ }^{6}$

The representation of mass military death, the subject of Minard's final works, had an established lineage, of which Minard would have been well aware, that extended beyond the terrain of statistics but was not disconnected from it. In their shared preoccupation with heroic defeat, we might discern unlikely affinities between Minard's late maps and contemporaneous works by an artist such as Alphonse de Neuville, who found celebrity in the early 1870s for his images of the Franco-Prussian War. The exhausted, freezing soldiers of de Neuville's image of the aftermath of the battle of Le Bourget, during the siege of Paris, the bloodied stretchers and ruined buildings, and the piles of weapons, musical instruments, and packs: all these things are not in Minard's map, and the close emotive charge of such a painting seems far from Minard's totalizing abstractions, which both embrace and displace the modes of representation they are in 
dialogue with. Yet while evidently operating in different visual idioms with contrary institutional prerogatives, both works offer forms of contemporary historical representation, addressing the present through a frame of reference inherited from the past yet urgently of their time. While their strategies diverged-de Neuville used a familiar genre to represent a contemporary subject; Minard depicted a familiar subject through contemporary means-they effectively offered different responses to the same question, how to represent history, in the present. This shared ground can be seen most overtly in Minard's Napoleon map, although to comprehend this design fully it must be viewed in relation to those that preceded it, for Minard's cold assessment of the density and trajectory of military death was made possible by his previous attention to the flows of people and goods, which consistently repressed the human cost of such dynamics. $<<$ COMP: fig. 2 approx. here $>>$

\section{An Immense Octopus}

$<$ FL $>$ Notwithstanding its polemical clarity, something about Minard's work, as scientist and chronophotographer ÉtienneJules Marey noted approvingly, always resisted representation. Marey, himself attentive to the movement of bodies and things in space, conducting experiments on insect and bird flight as well as the movement of air, accorded Minard a decisive role in the development of the graphic method.7 "He always attains 
striking effects," Marey wrote, "but nowhere does the graphic representation of the march of armies reach that degree of brutal eloquence which [in this image] seems to defy the pen of the historian."8 Marey's account of Minard's "defiance," his map's refusal of established historical praxis (and its graphic technologies), offers a powerful counterpoint to its ostensible lucidity, accumulation of sources, and rationalityits presentation of what Orit Halpern, in another context, terms "communicative objectivity."9 Marey described another of Minard's Cartes figuratives, a "precious mode of representation" illustrating the distribution of coal exported from England in 1850, as being "like the arms of an immense octopus." Claiming to have the map right in front of him (literally, "sous les yeux"), Marey noted the crudeness of the planisphere Minard had rendered. The world shown on the map was a mere frame for the elegant display of data, not its absolute referent; Minard defied the geographer's pen too. From England, Marey saw each cephalopod limb, or "black ribbon," spreading around the world and expressing, in thousands of tons, the quantity of coal that made a particular journey ${ }^{10}$

$<<$ COMP: fig. 3 approx. here $>>$

Marey's description is interesting on several levels. Minard made other maps representing the same topic, charting English coal exports in 1860 and 1864, but in all of these designs the "octopus" Marey observed was colored a pale green, 
rather than black, likely so as not to obscure the careful numbering of each global extremity. Minard did sometimes attempt an indexical link between the coloring of his maps and the phenomena they described, embracing more literal maneuvers where they suited his purposes. French wine exports appear in red, while the colors of an 1862 map of global migration in 1858 are clearly racialized: black for east Africa, brown for India, yellow for China. But in this instance, it seems to have been Marey, not Minard, who made the connection to coal's "black ribbons"-the underground seams exploited by England's industrial revolution proliferating phantasmagorically, as if in premonition of their smoky destination yet contained within tightly bordered plumes, on and above the seas. The empty white space of the maps sharpens this perception of lithographic ink as pollution. Marey's projections onto Minard's design show that, from the beginning, these maps enabled imaginative flight as much as they scrupulously chronicled information.

<<COMP: fig. 4 approx. here >>

As On Barak argues, the abstractions of Minard's coal maps serve two contradictory functions. On the one hand, they distract from the material qualities of the coal being transported, while on the other they "function as harbingers of very concrete terraforming that would follow suit in the coaling system."11 It is thus necessary to resist the seductions of Minard's sweeping worldview, which camouflages 
as an autonomous energy flow the nonlinear and heterodox material substances and processes, forms of labor, and complex institutional and disciplinary exchanges that characterized the global movement of coal. At the same time, as Barak observes, it is vital we acknowledge the unique effectiveness of such a diagram as a mechanism for producing forms of "world-making," its statistical empiricism and hallucinatory clarity working to powerful ideological ends in making intelligible the nineteenth century's expansion of the physical world.

Marey's octopus analogy-a distributed sensate intelligence made, here, of sedimentary carbon-has proved a durable cartographic nightmare. ${ }^{12}$ Visions of octopus-like forms straddling maps as emanations of radiating evil were a staple propaganda image from the late nineteenth century to the late twentieth, and as Barak notes, were and remain a highly effective metaphor for conceptualizing empire. ${ }^{13}$ Russia, the villain of Minard's Napoleon map, was a frequent target. One of the first such images, the Humoristische-Oorlogskaart, published by J.J. Brederode in Haarlem in 1870, coincided almost exactly with Minard's most famous design and gave rise to many imitations. Published the year before Marey's text, English civil servant F.W. Rose's Serio-Comic War Map for the Year 1877 reproduces Brederode's design faithfully and became popular, with versions appearing in multiple languages. ${ }^{14}$ Seemingly discerning an apparition of the "serio-comic" map"s 
ghastly stereotyping in Minard's restrained design for English coal exports, Marey adapted Rose's conservative pieties about Russian territorial expansion to an interpretation of English dominance in the global circulation of commodities. <<COMP: fig. 5 approx. here>>

Marey's spotlight on the 1850 coal map reveals an aspect of Minard's graphic practice sometimes hidden in an exclusive focus on his Napoleon map. For, as Gilles Palsky recognizes, Minard's cartography was without doubt "that of a privileged observer of the mechanisms of the Industrial Revolution, and notably of the mobility of men and goods."15 To that might be added the fact that he was a privileged observer of empire, the violent dislocations of which are serenely aestheticized in his charts. As Jacqueline Wernimont notes, quantification as a means of coming to terms with, and repressing, sublime horror has a long history. ${ }^{16}$ The body count-from early modern bills of mortality to insurance documents-as a performative genre of quantum media is bound to complex histories of mediation and is undergirded by (and productive of) categories of gender, class, and race. Sometimes this is hidden in plain sight. Minard's several maps documenting European cotton imports before, during, and after the American Civil War, which he made over a number of years, show a shift away from North American trade toward new producers, predominantly in Asia but also in North Africa, South America, and the Caribbean. ${ }^{17}$ Clouds of cotton traverse the seas in neat, linear 
formation, while the deep histories of the forced movements of people that enabled this trade are nowhere documented. Elsewhere, "emigration" does a lot of heavy lifting-the blank registration of the travel of people from East Africa to Jamaica, Martinique, and Guadeloupe is thick with euphemism, the smooth flows of Minard's graceful designs neutralizing more painful truths.

$<<$ COMP: fig. 6 approx. here $>$

Yet disaster haunted these calculations. Writing in his 1866 treatise La houille et I'exportation de la houille anglaise, Minard claimed for coal a status as a "vital element" whose global significance transcended the English context. Four inventions defined the nineteenth century, Minard wrote: the steamship, the locomotive, the electric telegraph, and photography. Of these, the first two would not exist were it not for steam, in turn made possible by coal. ${ }^{18}$ Yet, Minard asked his reader, his contemporaneous investigations into the effects of the American Civil War surely in mind, <extract begins heresallow for a moment the-in truth, unlikely-prospect of a coal shortage like the cotton shortage three years ago. It would be much more disastrous. Imagine an intense cholera epidemic in England or a sedition of coal workers or a suspension of maritime communications. What would become of the populations of Europe, which receive today more than five million tonnes of English coal? ${ }^{19}$ <extract ends here> 
$<$ FL>Concluding, Minard proposed a careful management of coal extraction and importation to ensure the safety of national defense in the case of war. In common with many nineteenthcentury speculations on the future, anxieties about total collapse were never far away. Preoccupied by conflict, disease, revolution, and technical failure, Minard's text offers an attempt to calibrate and insure against risk, to mitigate potential loss, to extenuate military calamity. ${ }^{20}$ I introduce these earlier designs and preoccupations because this approach, by turns euphoric and catastrophic, characterizes, too, Minard's most famous design, which, striking as it is, does not stand alone. The actuarial and economic concerns that subtended Minard's plotting of global trade can also be detected here in latent form (e.g., the Russian campaign, while presented as a war of liberation, had a more prosaic cause, as a means to prevent Alexander I from trading with the British). Moreover, the power of Minard's Napoleon map resides in its effectiveness as a historical allegory for a particularly modern experience of catastrophic exile. ${ }^{21}$ Just as his other designs soberly tracked the extraction and transport of plants, minerals, and people from the soil, so would violent uprooting and migration be the background for this work's production as well as its tacit subject. Here is Victorin Chevallier, Minard's son-in-law and biographer, describing Minard's fateful decision, on 11 September 1870, to leave Paris before the siege, deserting his 
books, papers, family members, and the office he had occupied for twenty-five years:

<extract begins here>Leaning on crutches, in the middle of this throng of women, of children, and of old people who fled as he did, he left for Bordeaux with one part of his family, carrying only one light bag and some studies already begun. He endured very well the fatigues of a night journey, and barely installed at Bordeaux, without resources other than his memory, he reapplied himself to work; but six weeks after his arrival, as strongly frightened of the present as of the future, he was taken for three days by an irresistible fever, and on October 24 he returned his soul, full with gratitude toward God. ${ }^{22}$ extract ends here>

<FL>Frail and infirm, Minard the exile died, age eighty-nine, just over a month after Paris entered lockdown. The reputation of his Napoleon map came posthumously, for it was one of his last designs. The affinities between the events recounted in Minard's map and the circumstances under which he made it must have been excruciating .

\section{Brutal Eloquence}

$<$ FL $>$ Published below a pendant map showing the movement of Hannibal's army from Spain into Italy, Minard's chart tracks the advance of Napoleon's troops into Russia (in brownish red) and their calamitous withdrawal (in black). "Brutal eloquence"-Marey's description-is about right, for the 
thickness of the lines corresponds to the number of remaining soldiers, each millimeter representing ten thousand men, close to the number who returned of the original 422,000 soldiers. But this is only one factor of the chart, for Minard's work aims to allow the viewer to grasp up to six dimensions at once, accompanied by supporting numerical evidence, and it tells its reader-viewer what it is doing at every point. Minard's maps, this one especially, are nothing if not overdetermined.

<<COMP: fig. 7 approx. here>>

Situating his data in a recognizable if often heavily adapted cartographic space and suspending mimetic veracity to more fully explicate the flows of people and goods (what Barak calls "statistical realism"), Minard was sensitive to what we might now term environmental history, another feature that carries over from his earlier maps to his Napoleon design. ${ }^{23}$ Minard also plotted the descending temperature, marked on the Réaumur scale, as the troops left Russia, enduring lows of minus thirty-seven degrees Centigrade, leading to devastating losses of life. ${ }^{24}$ In this late carte figurative, the white expanses of the paper, strafed by scarlet and black, present as frozen wastes. ${ }^{25}$ The harrowing history from above laid out to such limpid effect in Minard's composition exposed forms of embodiment that were historical in nature. Adverse climatic conditions are aligned with calamity, for only the retreat is correlated with temperature, whereas the reddish line showing 
the army advancing on Moscow does not overtly identify weather as a factor, with significant losses attributed to key battles instead. Again, color choice plays an understated yet deliberate role in enhancing the design's emotive power and its legibility. In fact, death due to heat exhaustion (as well as starvation and disease) killed two-thirds of the army before it reached Moscow, complicating the entropic drive of Minard's map. ${ }^{26}$

Minard's career in statistical maps was very much a second act, following a long and successful career as a civil engineer and then as instructor and later inspector general at the École nationale des Ponts et Chaussées. ${ }^{27}$ In the words of Chevallier, "for M. Minard retirement, far from resembling death, was like a second existence."28 An arresting description this, with Minard's acclaimed death-map-his calculation and transfiguring of loss-standing as the final act of his own second shot. In his late flourishing, from the 1840s onward, Minard made fifty-one cartes figuratives using diverse data visualization techniques, often in combination: pie charts, bar charts, mosaic plots, line graphs, and scaled flux maps such as his Napoleon graphic. His thematic cartography cast a wide net, addressing subjects from European rail travel to the ideal location of Parisian post offices, scaling and mapping the circulation of commodities such as cereals, wine, beef, or steel within the hexagon and across the world. All of these were self-published, in seemingly quite small print runs. ${ }^{29}$ The 
success of Minard's method was such that in 1861 Alexandre Cabanel's portrait of the influential statesman Eugène Rouher, displayed at the Salon that year, showed him next to one of Minard's maps. ${ }^{30}$ Minister of state from 1863 to 1869 and a key advisor of Napoleon III, Rouher played a significant role in disseminating Minard's designs among the higher echelons of public works administration, which seems to have been their primary audience, and he even presented them to the emperor. ${ }^{31}$ <<COMP: figs. 8-11 approx. here>>

Minard's maps plot time but also multitude. Theorizations of "mass" in an age when a definable mass culture asserted itself fully on a global scale, they foreground deracination and flux as conditions of modern life, while simultaneously working to plot the contours of such movements and in doing so to stabilize them. ${ }^{32}$ Yet considering this broader frame of reference in parallel with the Napoleon map's subject matter, we might discern in it a diagram of "abandonment" by the past and a concomitant isolation in modernity, what historian Peter Fritzsche identifies as a melancholic consequence of the Napoleonic Wars' massive displacements of people.33 Such displacements are rendered more profound by their transplantation to, and representation in, a different historical epoch, fifty-seven years later. As such, the Napoleon design seems to promise a lineage, even an explanation for current conditions. By approaching this carte figurative with a degree of interpretative naivete, focusing 
on its subject matter rather than situating it primarily within the broader successes and failures of the graphic method, we might understand this map's true purchase to lie in its status as a dislocated "Napoleonic" image, ricocheting between the early nineteenth century and the final days of the Second Empire. As such, forms of historical representation that came to the fore during and shortly after the Napoleonic period, rather than exclusively those of the late 1860s, are a key point of reference, as they were for Minard himself.

In comparison to the image of the Russian campaign, the Hannibal map seems the silent partner in the duo. Yet while they are often viewed separately, with the chart of Napoleon's army separated from its source, they shared the same sheet, were contained within the same frame, and were matched to the same scale (using different criteria of measurement). Although it has its own legend and sources, the Hannibal map is less stocked with information and is smoother, less raggedly compelling in its visual effect. Ultimately, it reinforces a mythology that is fully in accordance with Napoleon's own construction of self. During the First Empire this found its most coherent expression in the five versions of Jacques-Louis David's equestrian portrait Napoleon Crossing the Alps (18011805), in which Hannibal, his name inscribed on the rocks of the St. Bernard Pass, is shown to be Napoleon's forebear. Progressing down the sheet in chronological order from top to bottom, we are impelled to read the Hannibal map into its 
tragic counterpart below. While flipping the script here would be interesting, the maps cannot be interpreted straightforwardly the other way around. That is, the Hannibal design, too, is a deferred "Napoleonic" image in which the familiar charismatic mythos of the emperor returns in new ways.

Born in 1781, Minard was thirty-one at the time of the Russian campaign in 1812. Chevallier notes that Minard retained a "profound memory" of the waning days of the ancien régime. But the Revolution and empire were what shaped him. At thirteen, suffused with "patriotic zeal," he attempted to extract saltpeter from the earth of his cellar, presumably to use in gunpowder, a practical application of technical knowledge that was of a piece with revolutionary science's make-do approach to resource extraction. ${ }^{34}$ Fully a product of revolutionary scientific pedagogy, Minard's career as a civil engineer aligned with the huge infrastructural initiatives set in play during the empire. Minard experienced the Napoleonic wars at some proximity, having been posted to Antwerp during the siege in 1813. ${ }^{35}$ He was a good twenty to thirty years younger than the most influential scientists and engineers of the Revolution and empire-the likes of Antoine-Laurent Lavoisier, Antoine François Fourcroy, Nicolas-Jacques Conté, Gaspard Monge, Jean-Antoine Chaptal, or Pierre-Simon Laplacebut he inherited their innovations and institutions. Working in Paris on the Charleroi canal in 1804, following his studies 
at the École Polytechnique and the École des Ponts et Chaussées, Minard met the elder of the Montgolfier brothers, Joseph-Michel, an acquaintance of his schoolfriends Charles Bernard Désormes and Nicolas Clément. ${ }^{36}$ Despite the difference in age between the aeronaut and the young scientists, for a period the four of them became regular companions, meeting together most Sundays. ${ }^{37}$ Minard's maps came after years spent engineering liquid flows in canals and ports, but from the beginning his practical expertise was complemented by loftier perspectives. ${ }^{38}$

As Sandra Rendgen indicates, the engineer's oeuvre should be understood in relation to contemporary transformations in communication and transit technologies-steam locomotion, the railroad, and the telegraph in particular. ${ }^{39}$ Undoubtedly, Minard, who authored instruction manuals on canal building, was sensitive to new ways in which information, as well as goods, might be transported. ${ }^{40}$ Successive, and finally successful, attempts to lay a telegraph cable across the Atlantic in 1857-1858 and 1865-1866 (an undersea cable was installed between France and Britain in 1850) had transformed the speed at which information could be transmitted around the world, and closely anticipated Minard's Napoleon map. However, given Minard's past, a more pressing correspondence might be found to the optical, or aerial, telegraph developed by claude Chappe and his brothers in the 1790s, which sent semaphore messages across distance at unprecedented velocities and which 
operated in France from 1794 to the mid-1850s. ${ }^{41}$ Vital to Napoleon's territorial and military ambitions, the spread of the Chappe telegraph was made possible by new forms of cartographic knowledge that had accompanied the redivision of France during the Revolution. Not only was Minard's entire professional career until retirement conducted in the shadow of the Chappe telegraph's cryptic signals (canals and telegraphs often followed the same routes), but the system was associated indelibly with its use by Napoleon's armies, as it spread for 5,000 kilometers to all corners of the nation, crossing into the Netherlands, Belgium, and Northern Italy. Mobile versions were developed for the battlefield. Coincident with Minard's engineering career, the development of the optical system was of a piece with the history Minard sought to represent. And the telegraph of the early nineteenth century was, above all, a visual technology, limited to military use but visible from afar and dependent on coded gestures viewed through a telescope. Minard would have understood that Napoleonic communications infrastructure was distinct from the dematerialized, disembodied forms of transmission that accompanied the later shift to electrical telegraphy, and he would have known that its unique hardware engaged the senses-sight in particular-in order to function. Minard's Napoleon map was made by someone who, rather than projecting onto an imagined past, was remembering it and, at the time of its production, was drawing together two 
consequential periods of his life that corresponded to transformational events in French history. Unquestionably, too, the Napoleon map was made by someone who remembered the telling. While making use of multiple sources, as noted in the map's legend, including works by Adolphe Thiers, RaymondEmery-Philippe-Joseph de Montesquiou duc de Fezensac, Georges de Chambray, and the unpublished diary of Jacob, pharmacist of the army, Minard's map was particularly dependent on PhilippePaul comte de Ségur's Histoire de Napoléon et de la grande armée pendant I'année 1812, published in two volumes in 1824. Despite Marey's claim that Minard's work exceeded the competence of historians, multiple historical pens fed the "immense octopus."

These were not the only of Minard's graphic works to have a pronounced historical dimension. His final two statistical tableaux either side of the Napoleon and Hannibal pairing show the decline in the study of Latin in stuttgart High Schools from 1818 to 1864 , set against the rising number of students over the same period, and-his final work-the increase in the mean age of students at each level of promotion at the École Polytechnique from 1796 to $1863 .{ }^{42}$ Elsewhere, he traced the global dispersal of premodern languages, and in 1865 he offered a precursor to his Napoleon map in images comparing the arrangement of Charlemagne's forces against the Huns in $791 \mathrm{CE}$ to Napoleon's strategy against the Austrians in 1805. The latter work shows how closely Minard's historical 
references were tied to their contemporary media culture, as well as to the past. This, his first overtly historical map, was inspired by an article written that same month-February 1856-by Amédée Thierry in the Revue des deux mondes. Arguably, all of Minard's works in some way perform a historical task, albeit one often shot through with the time of the present. Such an approach pervades his writing, too, whether it be his assessment, published in the last year of his life, of the great constructions of the ancients-from the pyramids of Egypt and Mexico to the Great Wall of China-or his 1856 analysis of the future of Le Havre's port. ${ }^{43}$ According to Chevallier, alongside his interests in philosophy, history, and music, Minard followed public courses in paleontology, a late-stage product of what Georges Cuvier called the "age of description."44 And he was a voracious reader of contemporary histories, annotating passages he believed should be rectified or modified. ${ }^{45}$ The Napoleon and Hannibal images of military catastrophe remain the most dynamic in their historical reach and, unlike most of Minard's other images, do not make a direct comparison to, or gain authority from, more recent scenarios. Yet significantly, for Minard, history was always a matter of selection, revision, and redaction, a pliable medium that gained traction from its representation of the past in the present. And, as with the illustrated histories of the romantic school of French history that developed during the Restoration and July Monarchy and upon which he drew-peppered 
as they were with atmospheric wood-engraved vignettes and evocative culs de lampe-it was visual in both its methods and affective charge. ${ }^{46}$

Given this responsiveness to both the present time and to the drawn-out timescale of lived history, the lateness of Minard's Napoleon and Hannibal maps in his own career is worth pausing over. "Late works," as Theodor W. Adorno observes, are conventionally "relegated to the outer reaches of art, in the vicinity of document."47 So far so good, for Minard's maps assuredly reside in that "vicinity." Yet, late style, Adorno tells us, is not smooth or sweet, replete and full like a ripe fruit, but "spiny," "bitter," "furrowed," and "ravaged." Rather than an art of transcendence, harmony, or synthesis, Adorno's late style is that of a subjectivity alienated and contradictory, discarding the rules of the social order of art within which it evolved, its fragments unreconciled and irresolute, both objective and subjective. "In the history of art," he concludes, "late works are the catastrophes." 48 Moreover, late work, as Edward Said asserts in his meticulous reading of Adorno's compact and difficult text, is fundamentally exilic, "a kind of self-imposed exile from what is generally acceptable, coming after it, and surviving beyond it."49 My claims for Minard's late style are less ambitious than those Adorno makes for Ludwig van Beethoven (and those Said, in turn, makes for Adornol, and although Minard was himself forced into terminal exile shortly after making the 
map, the process it represents is ultimately one of bedraggled homecoming-after all, some of the soldiers in the Grande Armée are shown to have made it back to the Russian border, albeit at the dwindling end of the black needle. Nonetheless, if Minard's Napoleonic design is not quite an image of exile as normally understood, it is without doubt an image of deracination, of estrangement, "abandonment," and of "surviving beyond." That is, it makes palpable some of the processes of conquest and violence that without doubt pertained to his coal or cotton maps but were not expressed there, historical distance making it possible to visualize what could not be shown in maps treating more recent topics. Minard knew what the troops in 1812 could not yet know-that the leader of the Grande Armée, nowhere represented on the page, was to become the ultimate exilic hero. And the same week Minard deserted Paris, Bonaparte's nephew Napoleon III escaped in the opposite direction, first to Germany then to England, where he died three years later.

Minard's late maps are-more than anything-representations of crisis and failure, and in their jagged contours they are noticeably distinct from the swelling flows of most of his other "synthetic" flow charts. Octopus metaphors do not apply here. Commonly oriented to more obviously contemporary concerns, his earlier maps emphasize efficiency and rationality, prioritizing burgeoning velocities and amplitudes, as, for example, in his map plotting the 
circulation of combustible materials on French waterways and railways in 1856. On the contrary, Minard's biggest successes are, if you like, his catastrophes. Even the decline in Latin teaching in higher education that oddly preoccupied him in his last years fits this model. A cautious man, Minard was acutely attuned to processes of obsolescence and breakdown. Ever the practical engineer, in 1850 he glumly advised that infrastructure be built as quickly and cheaply as possible to offset this inevitability, rather than investing in more longlasting solutions, for "ultimately, there is no permanent utility."50

<<COMP: fig. 12 approx. here>>

\section{Fog of War}

$<$ FL>In an analysis of nineteenth-century warfare as an atmospheric phenomenon, via readings of Carl von Clausewitz, Stendhal, and, to a lesser extent, Minard, Anders EngbergPederson proposes that the Napoleon map "reveals how the passage through the space of war is a movement 'in a resistant medium.'" 51 For Engberg-Pederson, Minard's map illustrates the "friction" evident in Clausewitz's account of warfare-the "fog of war"-that stendhal was only partly able to reveal. Yet despite its promise to lay bare this "friction," and its ambition to resolve diverse factors in one seamless graphic, something in Minard's map-as Marey notes-poses a question without fully answering it. We have much data, elegantly 
presented, but its configuration is one that emphasizes its fundamental irreconcilability with the fact of historical distance.

So what exactly is the historical imaginary that Minard represents in his map? Or, to approach the matter from a possibly more revealing angle, what is left out? Despite its claim to represent everything, to quantify a historical sensorium, a great deal is excluded. To take just one example, Minard's Carte figurative omits women; their participation in war is not accommodated by the "hommes" of the title. Describing Minard's "marvel of economy," Daniel Rosenberg observes, in an insightful article, how the achievement of Minard's map lies partly in his careful elimination of information. ${ }^{52}$ Vital, for Rosenberg, is that we consider Minard's maps in relational terms, his broader practice serving as one further set of data against which the maps might make sense. Minard's Napoleon map is regularly understood in isolation, but it was usually presented alongside other designs, including the Hannibal map, but others, too, juxtapositions that transform them "from accounts of individual events into exemplars of imperial overreach, the historical power of geography, and the self-destructive cycles of war."53 They become, in short, allegories. Most compellingly, Rosenberg observes how "Minard's charts are characterized by a studied reticence. How many soldiers were killed in battles?" he asks. "How many wandered 
off? How many were done in by cold, hunger, disease, the brutal pressure of exhaustion, or the failure of the campaign?"54 We can, in summary, never have enough data. Here, for Rosenberg, and in the "artisanal" choices that merge with Minard's engineer's precision-the hand-drawn quality of the lithographs and background data work-is where the historicity of the image, as much as its informational aspect, resides. "By historical," he clarifies, "I am not referring to the history represented in the diagram-the history of Napoleon's wars-but rather to the history of Minard's own time embedded in the diagram."55 My argument here moves in a different direction, for it is precisely the dialectic between "Minard's own time"-if by that we mean just the late $1860 \mathrm{~s}$ rather than the longer timescale of his lived experience-and the "history represented in the diagram" that makes it so gripping, however drawn-out the distance between them.

Finally, while acknowledging the Napoleon map's evident success, Rosenberg asks the following questions: <extract begins here>what if one's goal is not to reveal data? What if the data in which one is interested has itself a graphic character? What if what one wishes to reveal is graphic rather than numerical? What if the aim of the argument is cultural or historical rather than scientific or social scientific? What if, instead of clarity, one aims first to express complexity? What if, instead of coherence, one aims 
first to express conflict, contradiction, and difference? ${ }^{56}<$ extract ends here>

$<$ FL>Rosenberg calls this "graphical critique," as opposed to Tufte's term, "graphical elegance." This is "an approach sharing values with studies in history, art, and philosophy. - . insisting on the significance of place, time, and culture in any representation."57 Minard's maps, Rosenberg implies, do not quite achieve this. The challenge posed by Rosenberg's questions is significant because they give us a language with which to read Minard's maps against the grain, outside the system they set up for themselves. However, I find more in the way of "graphical critique" in the maps than Rosenberg is willing to acknowledge, or perhaps than Minard intended. Setting to one side the intentionality that Rosenberg foregrounds-what one aims, what one wishes, what one's goal might be-Minard's Napoleon map might indeed be read reflexively, revealing, in the first instance, a graphic critique of its own graphic form, its complexity and "shared values" with other media and inquiries masked through a performative display of apparently distant, conclusive, and coherent historical data.

If Minard, as Marey writes, does indeed "defy the pen of the historian," one is compelled to ask, "What about the brush, pen, or burin of the artist"? Does Minard's work connect to other forms of representing the world in nineteenth-century France? How might Minard's images operate 
in productive tension with contemporaneous forms of representation that could offer a counterpoint to the maps' omnipotent aerial view? As we know, Minard's maps have strong connections to other forms of statistical representation, both before and after he was working, and in different national contexts. Yet to think more comprehensively about Minard's twinned Napoleon-Hannibal image-to truly consider it as a representation whose full import may be obscured as much as aided by the cold grammar of objectivity-we might better look elsewhere, away from strictly numerical data. These are cartes figuratives et approximatives after all. Without doubt, Minard himself understood his practice as participating in a far more capacious image world, one in which the burgeoning new media of nineteenth-century print culture and photography were paramount. Here he is in 1862:

<extract begins here>Today, figures apply to everything: advertisements for the sale of rural and urban properties, furniture, clothes, are always accompanied by plans and drawings; in the great criminal trials a map of the places is put before the eyes of the jurors. The New Year's book [Iivre d'étrennes] is more the work of the lithographer than the literary hack. In his fables, La Fontaine made animals speak; we want, in addition, Granville [sic] to have drawn their attitudes. In the projection for a publication, a photographer is attached to every expedition; there are not even books of science which do not have on the pages of the text, as was 
sometimes seen two hundred years ago, the image of the subjects they treat. Finally, illustration invades everything, and by rendering statistics figurative, I satisfied the need of the day, but did I do nothing but sacrifice to the taste of the time, and did I not contribute to an increase in usefulness and to shorten the time of statistical studies ${ }^{58}<$ extract ends here>

Minard's delicious martial metaphor, his account of visuality's "invasion," is hardly positive in tone but more a weary recognition of facts as they are. His case for his having been driven by the winds of fashion while simultaneously progressing his field of statistical studies feels like a request for absolution. Still, in an age of overwhelming visual distraction, in which attention was compromised, to "shorten the time" in which an image could be understood was vital. ${ }^{59}$ Delays of all kinds, as his Napoleon map shows, could be fatal. Interest in the rapid intelligibility of a visual message coincided with the drive to velocity that characterized Minard's work on the routes and waterways of France, an emphasis on efficient networks that in the first half of the century cut across social, intellectual, and technical practices from Monge to the Saint-Simonians. It was crucial for Minard that his maps be instantly comprehensible. Here he is again, in the same text: "I have heard it said, of my maps, that expressive maps [cartes parlantes] have been made for a long time; but not only do my 
maps speak, in addition they count, they calculate by the eye; this is the capital point."60

"Eloquence," however "brutal," did not imply vocalization. Yet calculation by the eye had its precedents and counterparts, and not all within the domain of scientific image making. The publication of Minard's final maps preempted by five years the first impressionist exhibition, and despite the vast gulf that separates their generic and stylistic worldviews, impressionism's prioritization of instantaneity makes for an interesting contemporary contrast with the combination of simultaneous perception and protracted data sampling evident in Minard's project. ${ }^{61}$ However, I have an earlier comparison in mind, one whose heyday was coincident with the Napoleonic period rather than with the production of the map, but which had not disappeared even then (see my earlier invocation of de Neuville working in the 1870s).

In an influential article, susan Siegfried describes two tendencies that governed the production of reality effects in early nineteenth-century paintings of large-scale military conflagration. Both emerged in the light of the reformation of the political ideology of battle painting after the French Revolution, when current events became a legitimate subject for art and the perspective of participants in conflict was newly validated.62 At one pole, an affective mode of representing battle emerged, typified by a painting such as Antoine-Jean Gros's 1801 Battle of Nazareth. At the other pole 
was a documentary style, in which Louis-François Lejeune's Battle of Marengo, made the same year, is exemplary. Neither, Siegfried argues, can be understood without the other. Lejeune's meticulous paintings take a distanced view of battle, surveying the field, whereas with Gros the action is immediate, all-encompassing, fragmentary, and chaotic. Formerly an engineer, Lejeune's military experience, and his participation at Marengo in particular, was considered an especial virtue, while Gros followed the army and equally embraced identification as a painter-soldier. Increasingly, a range of historical documents such as maps were deployed by battle painters, and from 1801 the state began to provide artists with official interpretations of conflicts. ${ }^{63}$ While both artists used precise cartographic documents-Gros's entry for the Nazareth competition does so excessively-Lejeune's documentary style was better received, however sanitized, distant, and based on propagandistic sources it may have been in comparison to Gros's metonymic fragmentation and immediacy. While Gros's turn to affect influenced a range of artists from Eugène Delacroix to Théodore Géricault, Siegfried concludes that Lejeune's documentary mode was ultimately the more radical, transforming the traditional idea of individual actions into an image of collective activity across all levels of the military hierarchy and finding later expression in popular entertainment, as his paintings served as models for panoramas. ${ }^{64}$ 
Taking a later example, Lejeune's 1822 Battle of Borodino represents a key moment of a battle from the Russian campaign, the attack on the Shevardino redoubt. Although not noted on Minard's chart, a sudden thinning of the red line-a loss of 100,000 troops-at the Moskowa River, not far from Moscow, marks the battle's location. Airborne atrocity is hard to avoid in Lejeune's stunning pileup of real-time effects, in a way that Minard's map cannot accommodate. Cannonballs whizz through the air, some meeting their targets, while the impact of others is seconds away. Plumes of smoke from gunfire and burning farms and carriages fill the sky. In the bottom righthand corner, a grenadier nonchalantly stops a lit grenade, rolling toward him, with his foot. In their attempt to ground multiple vectors in geographic space, to conjure a complete picture via an accumulation of carefully selected local details, both Lejeune's paintings and Minard's maps might be considered landscapes, too, albeit landscapes that register in concentrated form the pressure under which that category had also been placed in the decades following the French Revolution. As Katie Hornstein tells us, such paintings, in conjunction with the more explicitly cartographic and topographic forms that engaged the "territorial imaginary" of postrevolutionary France, were a crucial means by which French citizens were afforded opportunities to participate in geopolitical events. 65 
Sometimes, instead of a seemingly limitless accretion of details and effects, an aerial perspective did the work of joining viewers to participants. Italian architect and painter Giuseppe Pietro Bagetti's watercolor view of the march of the French army in Italy in 1800 during the Marengo campaign presents a stunning topographical vista, viewed as if from a reconnaissance balloon, that combines the immediate knowledge of the participant-artist with an uncanny projection of distant war. Yet these two modes were not exclusive, for as Hornstein argues, from the revolutionary wars onward, through the empire, Restoration, and July Monarchy, war imagery was a fully cross-media phenomenon that accumulated credibility because of familiarity with its conventions, and it was consumable via multiple images rather than by way of a single authoritative perspective. Connected closely to varied forms of mechanical reproduction, it was uniquely placed to mediate recent and historical events for audiences well versed in its diverse visual strategies.66

<<COMP: figs. 13-14 approx. here>>

Minard's carte figurative might be counted among the later effusions of the documentary mode of representing a battle, although it performs a reverse maneuver, taking multiple imagistic textual histories and turning them back into maps. It accords well to Mikhail Bakhtin's description of the novelistic chronotope, that "intersection of axes and fusion of indicators" in which "time, as it were, thickens, 
takes on flesh, becomes artistically visible; likewise, space becomes charged and responsive to the movements of time, plot and history."67 Indeed, the flow of soldiers in Minard's map "begins" with a dramatic, literary flourish as the troops depart: "the Cossacks gallop across the frozen Neman." The timescale here is unclear, however, for this must surely refer to Russian soldiers chasing the retreating French. The end is foreshadowed at the beginning, and the whole thing becomes a loop. 68 At other points, too, narrative legibility is compromised in the interests of overarching visual effect. While Minard's map necessarily simplified multiple retreats and advances, dispersals, and individual actions, the splitting of the black line at Botr, and then again at the westernmost limit of the flow, and its passing underneath the red line of advance, complicates the temporal coherence of the chart and reverses the order of events.

In such details, and in their multidimensionality, the past in Minard's maps is not only processed or recorded, but the possibility of an alternative history emerges. The first book-length iteration of what we now call counterfactual history, Louis-Napoléon Geoffroy-Château's Napoléon et la conquête du monde, 1812 à 1832: Histoire de la monarchie universelle, published in 1836, relates what would have happened had Napoleon not delayed at Moscow in 1812 and had he not been defeated at Waterloo. ${ }^{69}$ Geoffroy-Château recounts in detail the invasion of Britain and other imagined Napoleonic 
successes and inventions. Under Napoleon's victorious post1812 reign, the air itself would be suffused with the "voluptuous exhalations" of fine music, available to all. ${ }^{70}$ And doubtlessly, Minard would have welcomed the vast network of canals Geoffroy-Château claimed would have traversed the French Empire (for Geoffroy-Château, son of an engineering officer killed at Augsburg in 1803, infrastructure was key to this thwarted future). ${ }^{71}$ In 1831, Geoffroy-Château alleged, an eighteen-volume Grand atlas impérial would have been completed, rejuvenating the field of "philosophical geography." Immediately after, we read how "the language of numbers, dreamed of by Leibniz, was found and applied. Thought had its algebra, it could be expressed and formulated, understood by all, independently of the sounds and words which reproduce it so imperfectly."72 Many of Minard's maps are alert to this utopian idea of numbers communicating wordlessly, which becomes particularly charged in his Napoleon composition. Of course, counterfactualism was nothing new for utopian thinkers (nor, for that matter, military strategists). Overwhelmingly Bonapartist in tone, Geoffroy-Château's text is nonetheless haunted by the emperor's failures, his wrong decisions. We might think of Minard's map as a Kriegsspiel, a compendium of what-ifs and what-thens that set historicism in tension with forms of future-thinking. The chart of the Russian campaign-representing the exact same point of divergence in 1812 that Geoffroy-Chateau marks for his new 
beginning-prompts us to learn from the errors of history, to carve a different path.

\section{Family Trees}

$<$ FL $>$ Such prerogatives were pressing in late 1869 and early 1870, with war and civil war on the horizon, and even more so afterward. In this context, Minard's Napoleon map can be taken as a kind of history painting by another means, one that returned to certain modes of historical representation, largescale paintings of military conflagration and their many reproductions in particular, at a time when the authority of history painting and its ability to offer a totalizing vision was increasingly compromised. In this way, his map appears to mourn the promise of such works, or to compensate for their loss, by providing a comprehensible aerial image in the turbulent wake of the Second Empire, when contemporary events seemed set to fracture French society as never before. ${ }^{73}$

Yet to consider Minard's last maps solely in terms of the top-down oversight they promise seems, ultimately, a flawed means of accessing the historical imagination they adumbrate. For as with military painting of the Napoleonic era, they are fundamentally lateral in character, drawing in other times, other places, and other information regarding events both synchronous and asynchronous. The Napoleon and Hannibal maps' apparent proximity to ambitious military painting lies in their shared recourse to other kinds of data to make their 
case: maps, statistics, and eye-witness reports, as well as knowledge of infrastructures, military maneuvers, and local conditions. In the late 1860s, distinctions between media were becoming ever more unclear, as new image-making techniques mimicked those already in use, competing with them for market share and aesthetic authority. And, as Minard himself recognized, reproductive image-making, then "invading everything," provided an immediate context for his work: his designs, like those of painters, also looked sideways to the curtailed attention spans of contemporary consumers of illustration.

For Stefani Engelstein, such lateral thinking had wider applications. Encapsulated in the figure of the sibling, it cut across scientific, artistic, economic, and social practices and was central to the shaping of epistemologies and subjectivities in the European "long" nineteenth century. ${ }^{74}$ This was, too, the driving force of all counterfactual histories. "Histories," Engelstein tells us, "from their first emergence as explanatory forces, branched."75 Yet the relational networks that Engelstein describes offered no easy universalism. This vexed coming into view of fraternity's critical purchase-a specifically postrevolutionary experiencecan be observed in Lejeune's battle paintings, where participation and collective action across the ranks is idealized as a key aspect of the democratic postrevolutionary army. Such works, in their expert management of the horror of 
conflict, necessarily downplay the sibling violence intrinsic to war, pursuing instead more harmonious forms of resolution. ${ }^{76}$ Toward the end of his life, in March 1869, Minard remarked on the difficulty of distinguishing the causes of historical events from the statistical documentation of their effects. Skeptical, ultimately, of the viability of divining immutable historical laws in an age of rapid technological advancement, Minard intuited that the impact of photography, railroads, steamboats, and electromagnetism may not yet be visible to statistics. ${ }^{77}$ Perhaps Minard's late turn to historical subjects can be explained by this eleventh-hour misgiving about his own methods. Nonetheless, it is striking that in this analysis-written as he planned his Napoleon mapMinard gave particular credence to a venerable form of statistical history, the structure "at once figurative and chronological" of the family tree, with branches departing from a central trunk demarcating lateral relations as well as dynastic succession. ${ }^{78}$ Minard's own family history also embraced lateral moves: in 1822 he married the second daughter of his friend Désormes, whose elder daughter had married Clément, his other schoolfriend from Dijon ("and to the ties of friendship were added the ties of family"). ${ }^{79}$

Entailing separation from these familial roots, exile and migration-Minard's final condition and the subtext of many of his designs-are also unmistakably lateral in orientation, yet more traumatic in their effects. Minard's chart of Napoleonic 
expiration-this stark document of when soldiers in the Grande Armée breathed their last-had real-world parallels in 1812 and in Minard's old age, and its consequences branched too: even now, looking at these designs, the infographic mode summons us, asks us to form an opinion, to place ourselves on the map. But in the two years that followed its publication, the map's oblique appeal to histories and media past and present accrued more harrowing inflections.

In June 1869, just as Minard was working to complete the Napoleon map that would be published in November that year, Karl Marx's introduction to the publication of the second edition of the Eighteenth Brumaire criticized Pierre-Joseph Proudhon for falling into the trap of the "objective historians," noting how "French literature has made an end of the Napoleon legend with the weapons of historical research, criticism, satire, and wit."80 Although Marx's ambitions were evidently quite different from Minard's, his analysis of Napoleonic pastiche in the aftermath of 1848 shares with Minard's map a harnessing of past failures to critique the present. Minard's thematic cartography would, at first sight, seem to place him in the camp of the "objective historians." However, his late work's delineation of incompetence, disaster, and death, while it lacks the insight into class struggle Marx sought, was also a forensic undermining of all upon which the cult of the emperor was built, using the same diverse "weapons of historical research," among which we 
should include illustrated histories and paintings of historical conflict. And here, Minard's Napoleon map is haunted by another, darker shadow, against which it must, surely, be read. Because what could be more emblematic of fraternity's transformative possibilities, of the telescoping of revolutionary history, of sibling violence, of counterfactual what-iffery, and of catastrophic failure and loss than the Paris Commune that began just four months after Minard's death? The name of Thiers, its callous vanquisher, already looms large on Minard's Napoleon design. Now though, this later history explains the map, rather than the other way around; the future explains the past. As early as 1872 the last barricades of the Communards (in red) and the daily movements of avenging Versailles troops (in blue) were plotted, in a chronometric map by Meunier and Rouillier, whose impassive surface bore testimony, via its repression, to the horrific slaughter of the semaine sanglante and to the exile of thousands. There's your "brutal eloquence." <<COMP: fig. 15 approx. here>>

For generous and incisive feedback on early versions of this paper I am grateful to audiences and participants in "Exiled Landscapes in Nineteenth-Century France" at the 2018 Design History Society Annual Conference, New York, and "The Aerial Image," Yale University, in 2019. I am especially indebted to the editors of Grey Room-Emily Doucet, Matthew Hunter, and 
Nicholas Robbins-and to Iris Moon, Lynda Nead, John Durham Peters, and Kelly Presutti for their excellent suggestions. A Mid-Career Fellowship from the British Academy made it possible for me to research and write this article. Translations are mine unless otherwise noted.

1 On Minard's career, see Victorin Chevallier, "Notice nécrologique sur M. Minard, inspecteur général des Ponts et Chaussées en retraite," Annales des Ponts et Chaussées 15 (1871): 1-22; Pierre Hardouin Tarbé de Saint-Hardouin, Notices biographiques sur les ingénieurs des ponts et chaussées depuis la création du corps, en 1716, jusqu'à nos jours (Paris: Librairie Polytechnique Baudry et Cie, 1884), 151-53; François de Dainville, "Les Bases d'une cartographie industrielle de l'Europe au XIXe siècles," in La Cartographie reflet de I'Histoire (Geneva: Éditions Slatkine, 1986), 153-75; Michael Friendly, "Visions and Re-visions of Charles Joseph Minard," Journal of Educational and Behavioral Statistics 27, no. 1 (Spring 2002): 31-51; Menno-Jan Kraak, Mapping Time: Illustrated by Minard's Map of Napoleon's Russian Campaign of 1812 (Redlands, CA: Esri Press, 2014); Arthur H. Robinson, Early Thematic Mapping in the History of Cartography (Chicago: University of Chicago Press, 1982); and Arthur H. Robinson, "The Thematic Maps of Charles Joseph Minard," Imago Mundi 21 (1967): 95-108. See also the information in "Dossier de personnel: Ingénieurs des ponts et chaussées: Charles-Joseph 
Minard," in Archives Nationales, F14 2284-1. Minard's designs have been published in their entirety in Sandra Rendgen, The Minard System: The Graphical Works of Charles-Joseph Minard (Princeton, NJ: Princeton Architectural Press, 2018).

2 Edward R. Tufte, The Visual Display of Quantitative Information (Cheshire, CT: Graphics Press, 1983), 40. 3 Minard is also invoked as an antecedent of Jacques Bertin's structuralist diagrams in Alexander Campolo, "Signs and Sight: Jacques Bertin and the Visual Language of Structuralism," Grey Room, no. 78 (Winter 2020): 34-65.

4 Charles-Joseph Minard, Des tableaux graphiques et des cartes figuratives (Paris: Thunot, 1862), 4 and plate 4, fig. 4. 5 See Eva Horn, "Air as Medium," Grey Room, no. 73 (Fall $2018): 6-25$

6 On these, see Stephen Bann, Parallel Lines: Printmakers, Painters and Photographers in Nineteenth-Century France (New Haven: Yale University Press, 2001), 43-87.

7 See Inge Hinterwaldner, "Parallel Lines as Tools for Making Turbulence Visible," Representations 124 (2013): 1-42. 8 Étienne-Jules Marey, La méthode graphique dans les sciences expérimentales et principalement en physiologie et en médicine (Paris: G. Masson, 1878), 73. On the history of the graphic method, see H. Gray Funkhouser, "Historical Development of the Graphical Representation of Statistical Data," Osiris 3 $(1937): 269-404$. 
9 Orit Halpern, Beautiful Data: A History of Vision and Reason since 1945 (Durham, NC: Duke University Press, 2014), 1.

10 Marey, 75.

11 On Barak, Powering Empire: How Coal Made the Middle East and Sparked Global Carbonization (Berkeley and Los Angeles:

University of California Press, 2020), 8-9. See, too, Colin Fanning, "'The Indispensable Agent": Coal and Its

Displacements in Victorian England," Journal of Design History $34(2021)$.

12 See the insightful discussion of cephalopod imaginaries in Melody Jue, "Vampire Squid Media," Grey Room, no. 57 (Fall $2014): 82-105$

13 Barak, 8-11, 212-18.

14 Like Minard, Rose had a day job; a civil servant for fortytwo years, he became deputy principal clerk in the Legacy Office of the Inland Revenue at Somerset House. Roderick M. Barron, "Bringing the Map to Life: European Satirical Maps, 1845-1945," Belgeo 3-4 (2008): 445-64; and "Fred W. Rose [1849-1915]," Barron Maps, http://www.barronmaps.com/fred-wrose-1849-1915/.

15 Gilles Palsky, Des chiffres et des cartes: Naissance et développement de la cartographie quantitative au XIXe siècle (Paris: Comité des travaux historiques et scientifiques, 1996), 113. See, too, Josef W. Konvitz, Cartography in France, 
1660-1848: Science, Engineering, and Statecraft (Chicago: University of Chicago Press, 1987) .

16 Jacqueline Wernimont, Numbered Lives: Life and Death in Quantum Media (Cambridge, MA: MIT Press, 2018)

17 Painting, too, registered some of the ambiguities of this trade, as Michelle Foa describes in relation to Edgar Degas's 1873 A Cotton Office in New Orleans. Michelle Foa, "In Transit: Edgar Degas and the Matter of Cotton, between New World and Old," Art Bulletin 102, no. 3 (2020): 54-76. See, also, Anna Arabindan-Kesson, Black Bodies, White Gold: Art, Cotton, and Commerce in the Atlantic World (Princeton, NJ: Princeton University Press, 2021).

18 Charles-Joseph Minard, La houille et l'exportation de la houille anglaise (Paris: E. Thunot, 1866), 1.

19 Minard, La houille, 2; emphasis in original.

20 Note Maze's description of actuaries as "engineers of finance," in Georges Hamon, Histoire générale de l'assurance, en France et à l'étranger (Paris: L'Assurance Moderne, 1896), 72.

21 On exile and modernity, see Edward W. Said, "Reflections on Exile," in Reflections on Exile and other Essays (Cambridge, MA: Harvard University Press, 2002), 137-49. See, too, T.J. Demos, The Migrant Image: The Art and Politics of Documentary during Global Crisis (Durham, NC: Duke University Press, 2013). 
22 Chevallier, 21.

23 Barak, 212.

24 The Réaumur scale, which measures the boiling point at eighty degrees Centigrade under normal atmospheric pressure, had been replaced in France in the 1790s by the Celsius scale. However, the Réaumur scale continued to be used until the midnineteenth century in parts of Europe and Russia.

25 On diagrammatic blank spaces, see John Bender and Michael Marrinan, The Culture of Diagram (Stanford, CA: Stanford University Press, 2010) .

26 Jonathan Shay, "Casualties," Daedalus 140, no. 3 (2011): 180.

27 Friendly, 33.

28 Chevallier, 15.

29 Rendgen, 26.

30 Chevallier, 17; and Friendly, 33.

31 Minard described in 1861 how one of his maps representing cotton imports was shown to the emperor and was received positively. See Minard, Des tableaux graphiques, 6-7. 32 See Moritz Gleich, "Liquid Crowds: Regulatory Discourse and the Architecture of People Flows in the Nineteenth Century," Grey Room, no. 67 (Spring 2017): 44-63. Minard is discussed briefly on page 52 . 
33 Peter Fritzsche, Stranded in the Present: Modern Time and the Melancholy of History (Cambridge, MA: Harvard University Press, 2010).

34 Chevallier, 2. On saltpeter production during the Revolution, see Antoine-François Fourcroy, Rapport fait par Fourcroy, au nom du Comité de salut public, sur les arts qui ont servi à la défense de la République (Paris: Du Pont, 1795). See also Charles Coulston Gillispie, Science and Polity in France: The Revolutionary and Napoleonic Years (Princeton, NJ: Princeton University Press, 2004), 397-427.

35 Kraak, 2 .

36 For certification of Minard's École Polytechnique career, see Archives Nationales, AF/III/4 dossier 12, 83-86.

37 Chevallier, 3.

38 See, for instance, Minard, "Observations sur un système d'écluses à petites chutes," 1821, in Archives Nationales $F^{14}$ 3193.

39 Rendgen, 8; and Charles-Joseph Minard, Des Voyageurs internationaux sur le chemin de fer entre la Belgique et la Prusse (Paris: Thunot et Fain, 1846).

40 For instance, Charles-Joseph Minard, Cours de construction des ouvrages qui établissent la navigation des rivières et des canaux, professé à l'école des ponts et chaussées de 1832 à 1841 (Paris: Carilian-Goeury et Dalmont, 1841). 
41 See Richard Taws, "Telegraphic Images in Post-revolutionary France," Art History 39, no. 2 (April 2016) : 400-421. 42 Friendly, 36. The Stuttgart Latin chart is undated but was published in 1869, likely before the production of the Napoleon and Hannibal images in November that year. The École Polytechnique design is dated 6 May 1870.

43 Charles-Joseph Minard, Grandes constructions de quelques anciens peoples (Paris: Cusset, 1870); and Charles-Joseph Minard, De I'avenir nautique du Havre (Paris: E. Thunot, $1856)$.

44 Chevallier, 20; and Joanna Stalnaker, "Description and the Nonhuman View of Nature," Representations 135 (Summer 2016): $72-88$

45 Chevallier, 20.

46 Maurice Samuels, "Illustrated Historiography and the Image of the Past in Nineteenth-Century France," French Historical Studies 26, no. 2 (Spring 2003): 253-80.

47 Theodor W. Adorno, "Late Style in Beethoven" (1937), trans. Susan H. Gillespie, in Essays on Music (Berkeley and Los Angeles: University of California Press, 2002), 564. 48 Adorno, "Late Style," 567. 49 Edward W. Said, On Late Style: Music and Literature against the Grain (New York: Pantheon, 2006), 16. 
50 Charles-Joseph Minard, "Notions élémentaires d'économie politique appliqués aux travaux publics," Annales des Ponts et Chaussées, 2e série, 19 (1850): 75, cited in Palsky, 114. 51 Anders Engberg-Pedersen, "War Atmospheres," Textual Practice 32, no. 3 (2018): 437-53. On atmospheres of conflict, see, too, Mary A. Favret, War at a Distance: Romanticism and the Making of Modern Wartime (Princeton, NJ: Princeton University Press, 2009).

52 Daniel Rosenberg, "Against Infographics," Art Journal 74 $(2015): 38-57,53$.

53 Rosenberg, 54.

54 Rosenberg, 55 .

55 Rosenberg, 56.

56 Rosenberg, 56

57 Rosenberg, 57.

58 Minard, Des tableaux graphiques, 4.

59 The case for the nineteenth century's attention deficit has been made forcefully in Jonathan Crary, Suspensions of Perception: Attention, Spectacle, and Modern Culture (Cambridge, MA: MIT Press, 1999).

60 Minard, Des tableaux graphiques, 1.

61 See André Dombrowski, "Impressionism and the Standardization of Time: Claude Monet at Gare Saint-Lazare," Art Bulletin 102, no. 2 (June 2020): 91-120. 
62 Susan L. Siegfried, "Naked History: The Rhetoric of Military Painting in Postrevolutionary France," Art Bulletin 75, no. 2 (June 1993): 235-58.

63 On the "explosion in the production, dissemination, and use of cartography" (146) in military contexts, see Anders Engberg-Pedersen, Empire of Chance: The Napoleonic Wars and the Disorder of Things (Cambridge, MA: Harvard University Press, 2015), esp. 146-183. 64 Siegfried, 257. 65 Katie Hornstein, "The Territorial Imaginary of the Revolutionary and Napoleonic Wars," in Visual Culture and the Revolutionary and Napoleonic Wars, ed. Satish Padiyar, Philip Shaw, and Philippa Simpson (London: Routledge, 2017), 22. 66 Katie Hornstein, Picturing War in France, 1792-1856 (New Haven: Yale University Press, 2018).

67 M.M. Bakhtin, The Dialogic Imagination: Four Essays, trans. Caryl Emerson and Michael Holquist (Austin: University of Texas Press, 1982), 84-85.

68 As Daniel Rosenberg and Anthony Grafton write, "Minard's chart marks the centrality of the idea of reversal in the thinking and telling of history." Daniel Rosenberg and Anthony Grafton, Cartographies of Time: A History of the Timeline (New York: Princeton Architectural Press, 2010), 23. 
69 Louis-Napoléon Geoffroy-Château, Napoléon et la conquête du monde, 1812 à 1832: Histoire de la monarchie universelle

(Paris: H.-L. Delloye, 1836).

70 Geoffroy-Château, 471.

71 Geoffroy-Château, 149-51.

72 Geoffroy-Château, 460. On Leibniz and counterfactualism, see Catherine Gallagher, Telling It like It Wasn't: The

Counterfactual Imagination in History and Fiction (Chicago:

University of Chicago Press, 2018), 16-47. See also

Christopher Prendergast, Counterfactuals: Paths of the Might Have Been (London: Bloomsbury, 2019).

73 See Alastair Wright, "Mourning, Painting, and the Commune: Maximilien Luce's A Paris Street in 1871," Oxford Art Journal 32, no. 2 (2009): 223-42.

74 Stefani Engelstein, Sibling Action: The Genealogical Structure of Modernity (New York: Columbia University Press, $2017)$.

75 Engelstein, 7.

76 See Juliet Mitchell, Siblings: Sex and Violence (London: Polity, 2003).

77 Charles-Joseph Minard, La statistique (Paris: Cusset, 1869), 14 .

78 Minard, La statistique, 11.

79 Chevallier, 8. 
80 Karl Marx, preface to second edition of The Eighteenth Brumaire of Louis Bonaparte (1869)

https://www.marxists.org/archive/marx/works/1852/18thbrumaire/preface.htm. 